\title{
Special Issue: Denitrification in Agricultural Soils
}

\author{
Micòl Mastrocicco \\ Department of Environmental Biological and Pharmaceutical Sciences, Technologies University of Campania \\ "Luigi Vanvitelli" Via Vivaldi, 43-81100 Caserta (IT), Italy; micol.mastrocicco@unicampania.it; \\ Tel.: +39-0823-274605
}

Received: 22 May 2020; Accepted: 30 May 2020; Published: 1 June 2020

check for updates

\section{Introduction}

Denitrification, the main microbial reduction process of nitrate to the inert dinitrogen gas or to reactive gases such as nitric oxide and nitrous oxide [1], is a pivotal mechanism in agricultural soils, since it is the main attenuation mechanism for nitrate leaching towards groundwater [2-4]. Denitrification rates are challenging to estimate in the field, given large uncertainties due to measurement techniques and the absence of long-term measurements in different environmental and management settings in agricultural fields [5]. Moreover, it is acknowledged that major controls of denitrification might be directly or indirectly affected by plants and soils in agricultural systems [6].

\section{Advances in Understanding Denitrification in Agricultural Soils}

This special issue of the Earth Sciences and Geography section of Applied Sciences sought to collect studies in the areas of soil denitrification and related water quality issues. This is a specific topic characterized by different aspects and facets, such as atmospheric pollution due to greenhouse gases, surface water eutrophication, groundwater pollution by nitrate, and plant-soil interactions. For the above-mentioned reasons, the papers in this special issue provide an overview of the different points of view that different disciplines can use to tackle this global issue. In fact, anthropogenic nitrogen input in the global water cycle has already been recognized as a main driver in the changing global nitrogen biogeochemistry [7].

The contribution of Busico et al. [8] is on the watershed vulnerability assessment aspects of denitrification. They have analyzed four different watersheds located in the Mediterranean area (two in Italy and two in Greece), with a previously developed GIS vulnerability index called LOSN. They found that LOSN can identify portions of the landscape with higher potential denitrification directly enhancing the groundwater vulnerability assessment; although, the LOSN index only considers the topsoil, so they have incorporated it into other GIS vulnerability methods (SINTACS-SVN and DRASTIC-PA), to account for the whole aquifer vulnerability assessment. The proposed approach could be useful for a first screening in potentially vulnerable areas with scarce hydrogeological data.

Castaldelli et al. [9] provided a budget approach at the basin scale to account for missing nitrogen in agricultural landscapes. They employed agricultural statistics, water quality datasets, and results of laboratory experiments to set up a detailed nitrogen budget along the terrestrial-freshwater continuum. The presented study fosters discussion on how denitrification could be considered as the leading process of nitrate removal in heavily fertilized lowland soils.

Ferretti et al. [10] worked at the plot scale, investigating the effects of zeolites (natural and amended with pig slurry) on the $\mathrm{C}$ and $\mathrm{N}$ cycles. They combined crop yield with ${ }^{15} \mathrm{~N}$ isotope analyses in both soil and plants with $\mathrm{C} / \mathrm{N}$, humic substances, and fulvic acids to gain insights on the $\mathrm{N}$ and $\mathrm{C}$ turnover. In fact, this work focuses on analyzing $\mathrm{N}$ and $\mathrm{C}$ pools and ${ }^{15} \mathrm{~N}$ distribution in agricultural soils with the aim of understanding the effects of zeolite addition on the soil-plant system. They found that nitrate content was lower in natural zeolitite treatments, which led to a lower nitrate availability 
for denitrifying bacteria. Overall, they have shown very complex interactions between soil microbes, fungi, and plants. This further promotes new studies on the effective denitrification capacity in such complex environments.

Gumiero et al. [11] assessed the $\mathrm{N}$ budget in agricultural plots used for short rotation forestry crops amended with biogas plant digestate. They performed an $\mathrm{N}$ balance by comparing a short rotation forestry with a permanent meadow, both located in an area with highly permeable soils. They used two different amounts of digestate for each system. The results obtained indicate that, in the presence of highly permeable soils, the short rotation forestry is not effective in retaining $\mathrm{N}$ during the initial stage of growth, due to limited denitrification rates and high leaching rates. This case study can provide valuable information for integrated soil management in upland regions characterized by highly permeable soils.

Chen et al. [12] presented the most bioengineering-oriented manuscript of this special issue. They isolated Janthinobacterium svalbardensis F19 from sludge sediment, which is capable of simultaneously executing heterotrophic nitrification and aerobic denitrification under aerobic conditions. Their results indicate that this bacterial strain has the potential for efficient $\mathrm{N}$ removal at low $\mathrm{C} / \mathrm{N}$ ratios from domestic wastewater and in small farming systems.

Overall, the articles in this special issue give an overview of the different aspects of denitrification in agricultural soils, taken from different disciplines, such as soil physics, hydrogeology, bioengineering, soil ecology, agronomy, and biogeochemistry.

\section{Future Perspectives}

Although the special issue has been closed, more detailed studies on the mechanisms that drive denitrification in soils are expected in the near future. We believe that this special issue will further promote exchanges between scientific disciplines, and provide a forum for new multidisciplinary studies needed to better understand the complex interactions of the soil-water-plant-atmosphere continuum.

Funding: This research received no external funding.

Acknowledgments: This issue would not be imaginable without the contributions of numerous brilliant authors, many expert reviewers, and a dedicated editorial team of Applied Sciences.

Conflicts of Interest: The authors declare no conflict of interest.

\section{References}

1. Seitzinger, S.; Harrison, J.A.; Böhlke, J.K.; Bouwman, A.F.; Lowrance, R.; Peterson, B.; Tobias, C.; Drecht, G.V. Denitrification across landscapes and waterscapes: A synthesis. Ecol. Appl. 2006, 16, 2064-2090. [CrossRef]

2. Jahangir, M.M.; Khalil, M.I.; Johnston, P.; Cardenas, L.M.; Hatch, D.J.; Butler, M.; Barrette, M.; O'flaherty, V.; Richards, K.G. Denitrification potential in subsoils: A mechanism to reduce nitrate leaching to groundwater. Agric. Ecosyst. Environ. 2012, 147, 13-23. [CrossRef]

3. Keuskamp, J.A.; Van Drecht, G.; Bouwman, A.F. European-scale modelling of groundwater denitrification and associated $\mathrm{N}_{2} \mathrm{O}$ production. Environ. Poll. 2012, 165, 67-76. [CrossRef] [PubMed]

4. Caschetto, M.; Colombani, N.; Mastrocicco, M.; Petitta, M.; Aravena, R. Nitrogen and sulphur cycling in the saline coastal aquifer of Ferrara, Italy. A multi-isotope approach. Appl. Geochem. 2017, 76, 88-98. [CrossRef]

5. Hofstra, N.; Bouwman, A.F. Denitrification in Agricultural Soils: Summarizing Published Data and Estimating Global Annual Rates. Nutr. Cycl. Agroecosyst. 2005, 72, 267-278. [CrossRef]

6. Malique, F.; Ke, P.; Boettcher, J.; Dannenmann, M.; Butterbach-Bahl, K. Plant and soil effects on denitrification potential in agricultural soils. Plant Soil 2019, 439, 459-474. [CrossRef]

7. Schlesinger, W.H. On the fate of anthropogenic nitrogen. Proc. Natl. Acad. Sci. USA 2009, 106, $203-208$. [CrossRef] [PubMed]

8. Busico, G.; Kazakis, N.; Colombani, N.; Khosravi, K.; Voudouris, K.; Mastrocicco, M. The Importance of Incorporating Denitrification in the Assessment of Groundwater Vulnerability. Appl. Sci. 2020, 10, 2328. [CrossRef] 
9. Castaldelli, G.; Vincenzi, F.; Fano, E.A.; Soana, E. In Search for the Missing Nitrogen: Closing the Budget to Assess the Role of Denitrification in Agricultural Watersheds. Appl. Sci. 2020, 10, 2136. [CrossRef]

10. Ferretti, G.; Faccini, B.; Vittori Antisari, L.; Di Giuseppe, D.; Coltorti, M. ${ }^{15}$ N Natural Abundance, Nitrogen and Carbon Pools in Soil-Sorghum System Amended with Natural and $\mathrm{NH}_{4}{ }^{+}$-Enriched Zeolitites. Appl. Sci. 2019, 9, 4524. [CrossRef]

11. Gumiero, B.; Candoni, F.; Boz, B.; Da Borso, F.; Colombani, N. Nitrogen Budget of Short Rotation Forests Amended with Digestate in Highly Permeable Soils. Appl. Sci. 2019, 9, 4326. [CrossRef]

12. Chen, Y.; Jin, P.; Cui, Z.; Xu, T.; Zhao, R.; Zheng, Z. Identification and Characterization of Janthinobacterium svalbardensis F19, a Novel Low-C/N-Tolerant Denitrifying Bacterium. Appl. Sci. 2019, 9, 1937. [CrossRef]

(C) 2020 by the author. Licensee MDPI, Basel, Switzerland. This article is an open access article distributed under the terms and conditions of the Creative Commons Attribution (CC BY) license (http://creativecommons.org/licenses/by/4.0/). 